\title{
Hyporheic Exchange and Nutrient Uptake in A Forested and Urban Stream in the Southern Appalachians
}

\author{
Chase Batchelor ${ }^{1} \&$ Chuanhui $\mathrm{Gu}^{1}$ \\ ${ }^{1}$ Department of Geology, Appalachian State University, USA \\ Correspondence: Chuanhui Gu, Department of Geology, Appalachian State University, Boone, NC 28607, USA. \\ Tel: 1-828-262-7859. E-mail: guc@appstate.edu
}

Received: April 8, 2014 Accepted: May 7, 2014 Online Published: May 28, 2014

doi:10.5539/enrr.v4n3p56 URL: http://dx.doi.org/10.5539/enrr.v4n3p56

\begin{abstract}
Hyporheic exchange (HE) controls stream water quality by regulating biogeochemical processes, ecosystem functioning, and nutrient dynamics. The objective of this study was to better understand and quantify the extent of urban impact on HE and how that affects stream nutrient uptake. Hyporheic exchange and nutrient uptake were studied through tracer injection experiments in an urban stream, Boone Creek, and a forested stream, Winkler Creek in the Southern Appalachians, USA. In this study, two sets of metrics were evaluated including transient storage and nutrient uptake metrics. The average dimensionless transient storage metrics $F_{\text {med }}$, the fraction of the median travel time through a $200-\mathrm{m}$ reach that is due to transient storage, of Winkler Creek was found to be 3-fold greater than that of Boone Creek. With regard to nutrient uptake metrics, Boone Creek was found to have an uptake length 13 -fold longer and an uptake velocity 16.7 times slower than Winkler Creek. The results show a greater extent of HE and higher nutrient uptake in the forested stream than the urban stream, which indicate that urbanization can deteriorate stream ecosystem functions by reducing HE and nutrient retention capacity. As a result, extra amounts of nutrients might export downstream and create a eutrophication problem. Thus, hyporheic restoration is crucial and has to be taken into account in restoring the ecosystems of urban streams.
\end{abstract}

Keywords: hyporheic exchange, nutrient uptake, OTIS model, urban streams

\section{Introduction}

The hyporheic exchange (HE) is defined as the interaction between stream water and groundwater, where the stream water passes back and forth between the active channel and subsurface flow paths (Runkel, 1998). The zone of this exchange is characterized by saturated pore spaces, under sand or gravel stream beds (Hancock, 2002) and near the adjacent banks of the stream (Ryan, 2010), that contain some amount of water from the main stream channel (Boulton, Welty, \& Larson, 2010).An indication of channel complexity within streams (Grimm, 2005), this transitional zone exposes surface water solutes to alternating oxic and anoxic conditions as they are mixed within the groundwater flow system (Lautz \& Siegel, 2007). This plays a crucial role in stream ecosystem functioning with regard to physical characteristics (e.g. stream temperature), biogeochemical processes, (Ryan, 2010), and nutrient cyclings, which ultimately control the water quality of the stream (Lautz \& Siegel, 2007).

HE is driven by many physical attributes. Parent lithology of watersheds affects HE by controlling sediment porosity and hydraulic conductivity (Morrice, Valett, Dahm, \& Campana, 1997). In addition, bed topography (i.e. dunes and ripples in sediments) drives HE through changes in local hydraulics (Harvey \& Bencala 1993). Stream slope, morphology, and bed form (e.g. pool-step sequence, channel sinuosity, etc) also influence HE (Wondzell, 2005). As a result, extent of HE depends on a wide variety of factors including, but not limited to, sediment porosity and hydraulic conductivity, channel morphology, as well as strength of groundwater upwelling, discharge, and size of the channel (Hancock, 2002). Size of HE in the vertical and lateral directions can range anywhere from a few centimeters to tens of meters depending on all of the above stated factors (Kasahara \& Hill, 2000).

From a hydrological perspective, the hyporheic zone also has the potential to reduce peak discharge during storm events (Kasahara \& Hill, 2002), a quality of particular importance in urban areas with extensive impervious surfaces prone to stormrunoff. The ecological significance of HE is even greater than just hydrologic flux. HE brings oxygen and other substrates in and flushes wastes out (Hancock, 2002). This process lends itself to a 
buffer having the potential to impede pollutant transport within both surface water flow paths as well as ground water (Hester \& Gooseff, 2010). HE increases the contact time of stream water with chemically reactive sediments and microbial communities, which creates hot spots for biogeochemical processes (Findlay, 1995).

Given the permeable nature of hyporheic sediments, as nutrients flow through the hyporheic zone, it is reactively filtered (Trimmer et al., 2012). Hyporheic zonesalso provide a means for nitrogen (N) and other nutrients to be temporarily stored before they are lost downstream (Reidy \& Clinton, 2004). This longer residence time for materials and reactive filtration allows for nutrient processing and plays a crucial role in regulating the concentrations and forms of $\mathrm{N}$ exported downstream (Ensign \& Doyle, 2006).

One of the most studied, but still poorly understood nutrient cycling processes of the hyporheic zone is denitrification, a heterotrophic nitrate reduction in anaerobic conditions (Trimmer et al., 2012). When oxygen-rich stream water penetrates into slower moving subsurface sediments, dissolved oxygen (DO) can be quickly depleted due to microbial respiration, creating anaerobic conditions. It is under these anaerobic environments that nitrate $\left(\mathrm{NO}_{3}{ }^{-}\right)$can be used as an electron acceptor, and is further reduced to $\mathrm{N}$ gases. It has been argued that denitrificationis of paramount importance in keeping groundwater-fed streams healthy (Trimmer et al., 2012). The existence of hyporheic zones in streams increase residence time of $\mathrm{NO}_{3}^{-}$, which allows denitrification to occur through abiotic and biotic processes. During periods of high flow, the effectiveness of this process is hampered due to a decrease in the size of the hyporheic zone, indicating that the more extensive hyporheic exchange is, the more effective the process of denitrification is within a stream (Ranalli \& Macalady, 2010). The natural denitrification that occurs in the hyporheic zone cannot usually compensate for increased nitrogen loading from anthropogenic causes, which can lead to eutrophication downstream.

Urbanization has drawn increasing concern in regards to threatening aquatic ecosystem in recent decades (Grimm et al., 2005). About 75\% of the world's population lives in urban areas, yet urban areas make up only 2 $\%$ of the earth's surface (Paul \& Meyer, 2001). One of the foremost disturbances from urban development is the increase in impervious surfaces, which reduces soil infiltration capacities at the same time as increasing surface runoff. This results in flashy stream flow and in an increase in sediment and nutrient (e.g. $\mathrm{NO}_{3}{ }^{-}$) transport, both of which can affect the ecological integrity of streams (Paul \& Meyer, 2001).

Overall, the impact of urbanization on hyporheic exchange and nutrient cycling is still poorly understood (Hester \& Gooseff, 2010, abstract). Most previous research has been conducted at sites of relatively undisturbed streams (Kasahara \& Hill, 2006). These studies have beenbased on furthering our knowledge of the effects of hyporheic exchange on biological habitat, nutrient cycling, pollutant buffering, and temperature regulation within stream systems in non-urban settings (e.g. Hester \& Gooseff, 2010). There has been significantly less research conducted on how urbanization can affect these facets of hyporheic flow functioning and nutrient cycling, with a few exceptions thatcharacterize the change in streambed sediments and solute transport and storage in response to urbanization (e.g. Ryan \& Packman, 2006; Ryan et al., 2010).

The objective of this study was to better understand and quantify the extent of urban impact on HE and how that affects stream nutrient retention (e.g. nitrate uptake). In this study, we aimed to test the hypothesis that HE and its nitrate uptakecapacity degrade with urbanization.

\section{Materials and Methods}

The study sites are located in the Upper South Fork of the New River watershed (USFNR), which includes the Town of Boone in the Blue Ridge Physiographic Province in northwestern North Carolina (Figure 1). The streams we studied are $3^{\text {rd }}$ and $4^{\text {th }}$ order perennial streams, Boone Creek and Winkler Creek, respectively, nested in the headwaters of the Upper South Fork of the New River watershed (USFNR). Having a channel gradient over $0.02 \mathrm{~m} / \mathrm{m}$, Boone Creek and Winkler Creek can be classified as a mountain stream with high topographic relief, extreme seasonal precipitation, thin soils, and close proximity of hillslopes (Turner, Colby, Csontos, \& Batten, 2013). The two watersheds share similarities in drainage area, climate, relief, and bedrock geology, which make them highly comparable paired sub-basins with which to screen out land-use impacts on HE and nitrate uptake.

Boone Creek is an urban stream influenced by high-gradient tributaries (Rice, Anderson, \& Thaxton, 2011) from the adjacent mountain slopes (Anderson, Anderson, Thaxton, \& Babyak, 2010). Despite these tributaries, Boone Creek's mean annual discharge is around $0.1 \mathrm{~m}^{3} / \mathrm{s}$ (Anderson, Storniolo, \& Rice, 2011). The watershed area of Boone Creek is approximately $5.3 \mathrm{~km}^{2}$. The stream channel averages $2.8 \mathrm{~m}$ in width and $20 \mathrm{~cm}$ in depth. Located in the heart of the university's campus, Boone Creek is urbanized with approximately $23.5 \%$ impervious cover (Coffey, 2011). The percentage of riparian coverage, forested area within a $12.2 \mathrm{~m}$ buffer of the streams, in the 
drainage area is $48 \%$. Boone Creek suffers from a lack of riparian vegetation, channelization, and incised channels due to its close proximity to roads, parking lots, and campus buildings (Anderson et al., 2010) (Figure 2). The streambed sediment is composed of gravels with isolated presence of sandy bar.

The watershed area of Winkler Creek is approximately $7 \mathrm{~km}^{2}$. The stream channel averages $3.8 \mathrm{~m}$ in width and $20 \mathrm{~cm}$ in depth. Winkler Creek has been left largely undisturbed with only $3.76 \%$ impervious cover (Coffey, 2011). The percentage of riparian coverage in the drainage area is $81 \%$ (Figure 2). Winkler Creek's annual mean discharge is about $0.2 \mathrm{~m}^{3} / \mathrm{s}$. Stream bed sediments of Winkler Creekprimarily consist of gravels, cobbles and boulders.

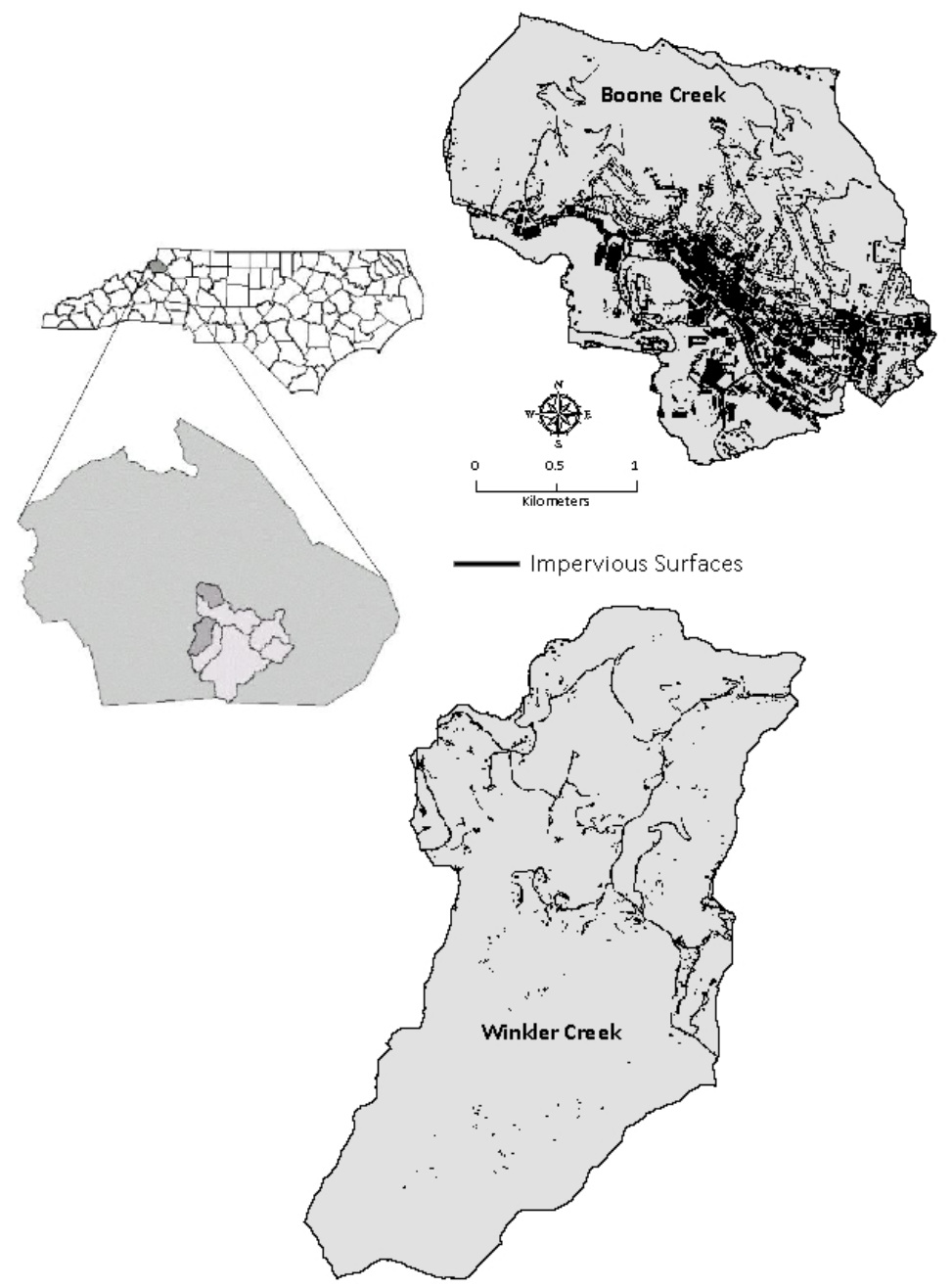

Figure 1. Map of winkler creek and boone creek watersheds in upper south fork of the new river watershed located in Boone, $\mathrm{NC}$ 
A

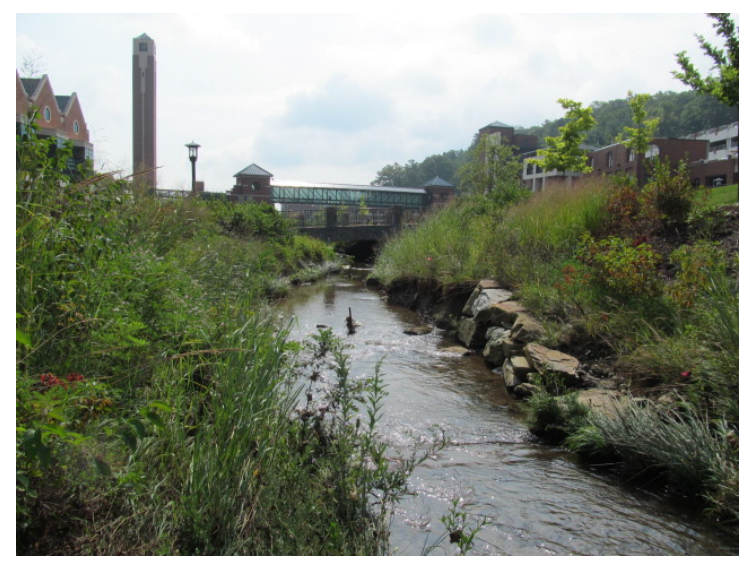

B

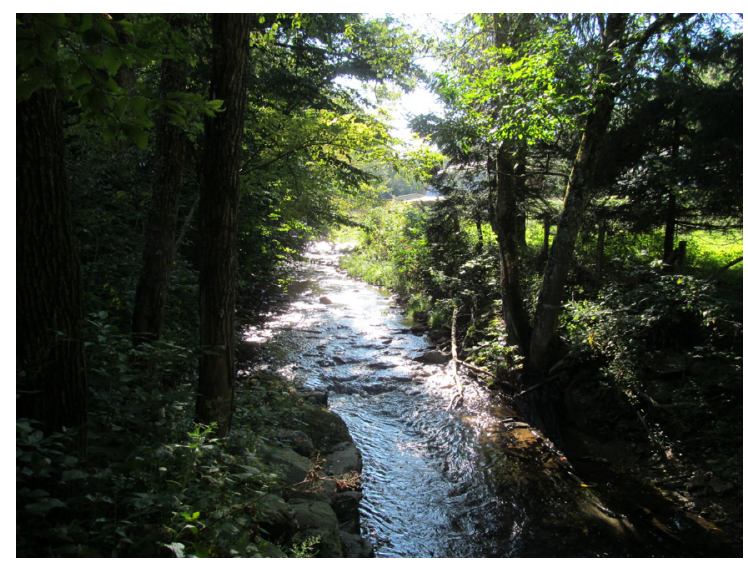

Figure 2. The studied reaches of Boone Creek (A) and Winkler Creek (B). Note the lack of riparian cover as well as extensive urban development on Boone Creek compared to Winkler Creek

Bromide and nitrate tracer experiments were conducted in baseflow conditionon October 9, 2013, along two 100-m stream reaches of Boone Creek and Winkler Creek. Two stream reaches with similar channel geomorphic characteristics from each creek were chosen. These two reaches are relatively straight and homogeneous in terms of substrate.Preliminary tests using $\mathrm{NaCl}$ were carried out for estimating mean travel times and designing the details of the later tracer injection experiments. Channel's widths were measured to decide the minimum length (i.e. $>20$ times of channel length) for mixing and dispersion of injected tracers. The experimental reach length of $100 \mathrm{~m}$ was adapted for this study.

For each field experiment, ambient specific conductivity of stream water was measured by aYSI multi-parameter probe at the downstream sampling sites of the experimental reaches. A non-conservative tracer, $\mathrm{NaNO}_{3}{ }^{-}$, as well as a conservative tracer, $\mathrm{NaBr}$,were then dissolved in a Marriotte bottle of stream water. The injectate concentration was aimed at raising Br- background by $1-2 \mathrm{mg} \mathrm{L}^{-1}$ (background was below the detection limit) and $\mathrm{NO}_{3}{ }^{-}$concentration by $2-3 \mathrm{mg} / \mathrm{L}$ (background $\mathrm{NO}_{3}{ }^{-}$concentrations were about $1.5 \mathrm{mg} / \mathrm{L}$ and $7 \mathrm{mg} / \mathrm{L}$ for Winkler Creek and Boone Creek, respectively).The stream discharge can be estimated based on total mass of tracer injected using Equation 1 (Ryan, Larson, \& Welty, 2011),

$$
Q_{s}=Q_{i} C_{i} /\left(C_{s}-C_{b}\right)
$$

where $Q_{i}$ is tracer injection rate in $\mathrm{L} / \mathrm{s}, Q_{s}$ isbaseflow discharge in $\mathrm{L} / \mathrm{s}, C_{s}$ is plateau concentration in $\mathrm{mg} / \mathrm{L}, C_{b}$ is ambient tracer concentration in $\mathrm{mg} / \mathrm{L}$, and $C_{i}$ isthe tracer concentration in the release solution.

The sampling stations were located in well-mixed areas at $50 \mathrm{~m}$ and $100 \mathrm{~m}$ downstream from the injection stations. A folding table was set up in the middle of the channel at the upstream sites from which the mixed injection solution was dripped from the Mariotte bottle at a rate of around $30 \mathrm{~L} / \mathrm{hr}$, for a duration ranging from 30 to 60 minutes for different experiments. YSI probes were positioned securely at $100 \mathrm{~m}$ downstream sites, to measure specific conductivity (SC) every $15 \mathrm{~s}$ during the entirety of the experiment. Stream water samples for $\mathrm{Br}^{-}$and $\mathrm{NO}_{3}{ }^{-}$were collected as grab samples in the well-mixed areas, always in the same spot. Station operators were equipped with synchronized watches and collected samples every minute. The grab samples were collected using $20 \mathrm{~mL}$ cone-cap vials that had been rinsed with stream water prior to sampling. After injections were finished, stream water continued to be collected until a recession tail had been captured and the stream chemistry completely returned to background conditions. A longitudinal synoptic stream survey at every $10 \mathrm{~m}$ was conducted when stream chemistry reached steady-state condition (i.e. BTC reaches plateau). The samples were taken back to the lab right after the field experiment and filtered through a Nylon membrane syringe filter with a pore size of $0.45 \mu \mathrm{m}$. $\mathrm{Br}^{-}$and $\mathrm{NO}_{3}{ }^{-}$concentrations were analyzed on an ion chromatograph (Dionex 1600) at the Clean Prep lab in the Department of Geology.

The USGS One-Dimensional Transport with Inflow and Storage (OTIS) computer software package was used to model the transport of water-borne solutes in Boone and Winkler Creek. Used in conjunction with gathered tracer injection field data, we quantified the HE metrics and nutrient uptake metricswithin these two streams. 
Originally developed for use in small mountain streams, the OTIS model assumes that solute mass is uniformly distributed over the stream's cross-sectional area and that concentration does not vary with depth or width (Runkel, 1998). The OTIS modelis governed by Equations 2 and 3 from Runkel (1998),

$$
\begin{gathered}
\frac{\partial \mathrm{C}}{\partial \mathrm{t}}=\frac{-\mathrm{Q}}{\mathrm{A}} \frac{\partial \mathrm{C}}{\partial \mathrm{x}}+\frac{1}{\mathrm{~A}} \frac{\partial}{\partial \mathrm{x}}\left[\mathrm{AD} \frac{\partial \mathrm{C}}{\partial \mathrm{x}}\right]+\frac{\mathrm{Q}_{\mathrm{L}}}{\mathrm{A}}\left(\mathrm{C}_{\mathrm{L}}-\mathrm{C}\right)+\alpha\left(\mathrm{C}_{\mathrm{s}}-\mathrm{C}\right)-\lambda_{\mathrm{m}} \mathrm{C} \\
\frac{\partial \mathrm{C}_{\mathrm{s}}}{\partial \mathrm{t}}=\alpha \frac{\mathrm{A}}{\mathrm{A}_{\mathrm{s}}}\left(\mathrm{C}-\mathrm{C}_{\mathrm{s}}\right)-\lambda_{\mathrm{s}} \mathrm{C}_{\mathrm{s}}
\end{gathered}
$$

where $C$ is solute concentration, $t$ is time, $Q$ is discharge, $A$ is the cross-sectional area, $x$ is distance, $D$ is a dispersion coefficient, $Q_{L}$ is the lateral inflow per unit length of stream, $C_{L}$ is the solute concentration in lateral inputs, $\alpha$ is a coefficient for storage zone exchange, $C_{s}$ is the solute concentration in transient storage zones, $A_{s}$ is the cross-sectional area of the storage zone, and $\lambda_{m}$ and $\lambda_{s}$ are first-order uptake coefficients for main channel and storage zone, respectively Equation 2 is an advection-dispersion-reaction equation that describes how advection, dispersion, transient storage, and reaction change tracer concentrations over time and space in the main channel and storage zones of streams (Lautz \& Siegel, 2007).

The OTIS model has been applied extensively to estimate the timing, magnitude, duration and fate of environmentally important solutes in streams and rivers (Stream Solute Workshop, 1990). By inverse modeling of the concentration-time histories of each tracer at each stream, we were able to estimate stream transport and reaction parameters with the OTIS model through curve fitting (Drummond et al., 2012). These parameters helped us to characterize the hydro-biogeochemical processes involved in in-stream solute transport (Wang, 2002). The conservative tracer $\left(\mathrm{Br}^{-}\right) \mathrm{BTC}$ was used to estimate $\mathrm{HE}$ (i.e.transient storage) metrics including exchange coefficient $(\alpha)$, cross sectional area of channel $(A)$, cross sectional area of storage zone $\left(A_{s}\right)$, and dispersion coefficient $(D)$ using the reverse modeling capability of OTIS-P, an automatic parameter estimation by Nonlinear Least Square fit (Runkel, 1998). This procedure can be repeated, until an acceptable match between simulated and observed values is reached so that a set of optimal-fit parameters can be identified.

The dimensionless transient storage metrics $F_{\text {med }}$ was calculated based on $A_{s}, \alpha$ and velocity. $F_{\text {med }}$ quantifies the percentage of the median travel time of a solute mass down a $200 \mathrm{~m}$ reach that is due to transient storage (Runkel, 2002). As such, $F_{m e d}$ was preferred over other transient-storage metrics as it includes stream velocity and exchange rate coefficient. $F_{m e d}$ can be calculated as:

$$
F_{\text {med }}=\left(1-\mathrm{e}^{-L \alpha / u}\right) A_{s} /\left(A+A_{s}\right)
$$

After the transient-storage parameters were estimated, these parameters were held constant. OTIS then computes the first order uptake coefficients of nitrate $\left(\lambda_{m}\right.$ and $\left.\lambda_{s}\right)$ from the nonconservative tracer $\left(\mathrm{NO}_{3}{ }^{-}\right)$BTC. The nutrient-uptake metrics including uptake length $\left(S_{w}\right)$, uptake rate $(U)$, and uptake velocity $\left(V_{f}\right)$ were then calculated from $\lambda_{m}$ values, stream velocity $(u)$, and stream depth $(h)$, and concentration of nitrate $(C)$.

$$
\begin{gathered}
S_{w}=(u \times h) / v_{f} \\
U=\lambda_{m} \times h \times C \\
v_{f}=h \times \lambda_{m}
\end{gathered}
$$

\section{Results}

The observed breakthrough curves (BTC) of $\mathrm{NO}_{3}{ }^{-}$tracer from all experiments were compared with OTIS model simulation using the optimized parameter sets. The sample comparison plot at the first sampling site $50 \mathrm{~m}$ downstream from injection site of Winkler Creekwas presented in Figure 3. Overall, the model captured the rising and falling limbs of $\mathrm{Br}^{-}$and $\mathrm{NO}_{3}{ }^{-}$breakthrough curves moderately well. The residual sum of squares (RSS) for $\mathrm{Br}^{-}$and $\mathrm{NO}_{3}{ }^{-}$were 5.3 and 4.6, respectively. 


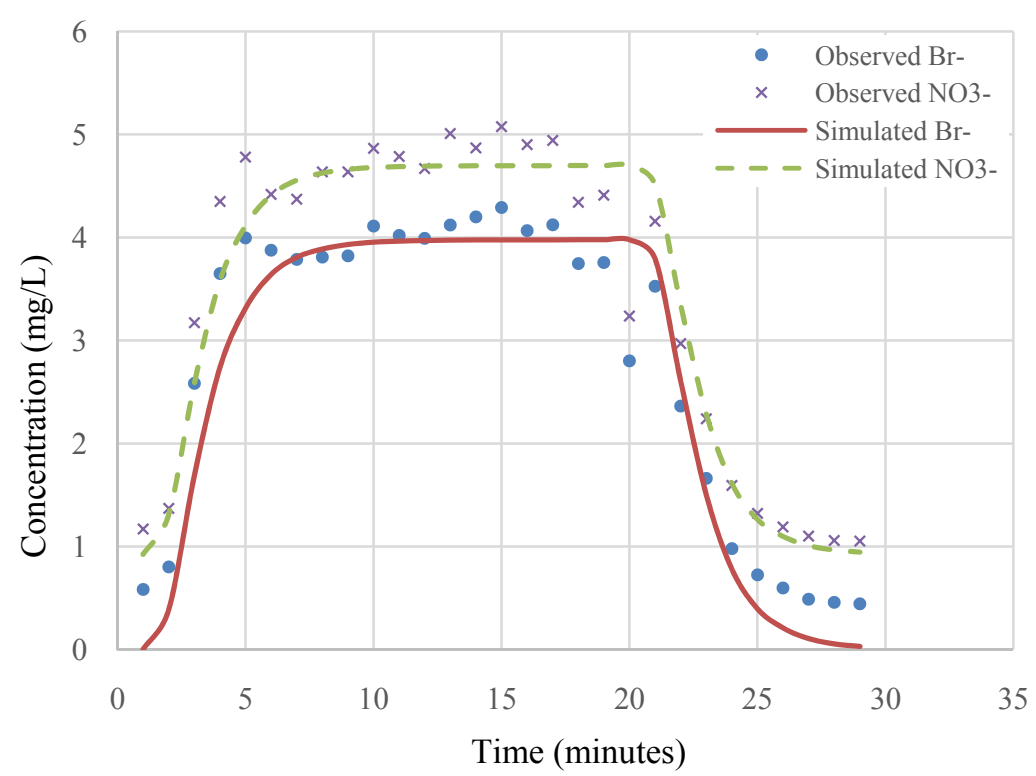

Figure 3. Comparison between observed and OTIS simulated $\mathrm{Br}^{-}$and $\mathrm{NO}_{3}{ }^{-}$concentrations at the first sampling site $50 \mathrm{~m}$ downstream from injection site of Winkler Creek

Various transient storage metrics of both Boone Creek and Winkler Creek estimated by the OTIS were summarized in Table 1. The average HE rate coefficient $\alpha$ of Boone Creek was $51 \%$ higher than that of Winkler Creek. The average cross-sectional area of the storage zone, $A_{s}$, in Winkler Creek was almost six times as large as that of Boone Creek. Given these areas, Winkler Creek had a ratio of storage zone cross-sectional area to stream cross-sectional area, $A_{s} / A$, of 0.29 while Boone Creek's $A_{s} / A$ was 0.036 . Finally, the averagedimensionless transient storage metrics $F_{\text {med }}$ of Winkler Creek is 3.0-fold greater than that of Boone Creek.

Table 1. Estimated transient storage metricsfrom OTIS model fit

\begin{tabular}{cccccc}
\hline Metrics & $\alpha(/ s)$ & $A\left(L^{2}\right)$ & $A_{s}\left(L^{2}\right)$ & $D\left(L^{2} / s\right)$ & $F_{\text {med }}$ \\
\hline Boone Creek - 50 m downstream & $1.63 \mathrm{E}-04$ & 0.67 & $5.17 \mathrm{E}-03$ & 0.60 & $1.83 \mathrm{E}-03$ \\
Boone Creek - 100 m downstream & $6.14 \mathrm{E}-05$ & 0.52 & 0.0382 & 0.27 & $5.25 \mathrm{E}-03$ \\
Boone Creek - Average & $1.12 \mathrm{E}-04$ & 0.6 & $2.17 \mathrm{E}-02$ & 0.44 & $3.54 \mathrm{E}-03$ \\
Winkler Creek - 50 m downstream & $3.25 \mathrm{E}-05$ & 0.36 & 0.17 & 2.07 & $7.02 \mathrm{E}-03$ \\
Winkler Creek - 100 m downstream & $1.16 \mathrm{E}-04$ & 0.49 & 0.08 & 0.33 & $1.40 \mathrm{E}-02$ \\
Winkler Creek-Average & $7.43 \mathrm{E}-05$ & 0.43 & 0.13 & 1.20 & $1.05 \mathrm{E}-02$ \\
\hline
\end{tabular}

From the estimated first order reaction rate constant of the main stream channels of Boone and Winkler Creek $\left(\lambda_{m}\right)$, the following nutrient uptake parameters were calculated: uptake length $\left(S_{w}\right)$, uptake rate $(U)$, and uptake velocity $\left(v_{f}\right)$ (Table 2). The average $\lambda_{m}$ of Boone Creek and Winkler Creek were $8.76 \times 10^{-6} \mathrm{~s}^{-1}$ and $2.84 \times 10^{-4} \mathrm{~s}^{-1}$, respectively, with Winkler Creek being almost 32 times greater. Winkler Creek has both the higher uptake rate (6.7-fold) and faster uptake velocity (16.7-fold) than Boone Creek. Boone Creek has the more than 13-fold longer uptake length than Winkler Creek. 
Table 2. Estimated nutrient uptake metrics from OTIS model fit

\begin{tabular}{cccccc}
\hline Nutrient Uptake Metrics & $\lambda_{\mathrm{m}}\left(\mathrm{s}^{-1}\right)$ & $\lambda_{\text {str }}\left(\mathrm{s}^{-1}\right)$ & $S_{w}(\mathrm{~m})$ & $10^{-5} U\left(\mathrm{~g} / \mathrm{m}^{2} \mathrm{~s}\right)$ & $10^{-6} v_{f}(\mathrm{~m} / \mathrm{s})$ \\
\hline Boone Creek - 50 m downstream & $8.82 \mathrm{E}-6$ & $2.31 \mathrm{E}-06$ & 13500 & 2.26 & 1.94 \\
Boone Creek - 100 m downstream & $8.70 \mathrm{E}-6$ & $4.56 \mathrm{E}-08$ & 17700 & 2.23 & 1.91 \\
Boone Creek - Average & $8.76 \mathrm{E}-06$ & $1.18 \mathrm{E}-06$ & 15600 & 2.245 & 1.925 \\
Winkler Creek - 50 m downstream & $4.33 \mathrm{E}-4$ & $1.03 \mathrm{E}-04$ & 641 & 22.9 & 52 \\
Winkler Creek - 100 m downstream & $1.34 \mathrm{E}-4$ & $8.43 \mathrm{E}-05$ & 1670 & 7.08 & 16.1 \\
Winkler Creek - Average & $2.84 \mathrm{E}-04$ & $9.37 \mathrm{E}-05$ & 1155.5 & 14.99 & 34.05 \\
\hline
\end{tabular}

\section{Discussion}

The influence of urban sprawl on HE and nutrient uptakes was investigated using continuous bromide (i.e. conservative) and nitrate (reactive) tracer injections. Inverse modeling on the tracer breakthrough curves using a stream solute transport models OTIS provide both physical and biochemical metrics for quantifying and comparing HE and nutrient uptake processes across streams. Distinct differences were observed in HE and nutrient uptakes on two streams. Human-alteration to streams would disturb hydrologic exchange between stream and groundwater. The absolute and relative cross-sectional areas of the storage zone (i.e. $A_{s}$ and $A_{s} / A$ ) in Winkler Creek are larger than those in Boone Creek. Thus, the solute retention time in storage zone, calculated as $A_{s} /(A \times \alpha)$, for Winkler Creek is more than 20-fold longer than Boone Creek, which might be attributed to reduced stream channel complexity in urban streams. Channel complexity such as pool-riffle sequence, sinuosity, streambed irregularity, debris dams, etc. is the major geomorphic driver of HE. Winkler Creek is characterized by a variety of bedform irregularity such as big boulders, backwaters, point bars, and riffle-pools. In contrast, the stream channel of Boone Creek was modified through a restoration project in 2011 and characterized by relatively straight channel and armored bank. In addition, the transient zone size is also affected by the nature substrate (bed material). The streambed of Winkler Creek is made up of sorted cobble and gravels, which should be more conducive to HE than non-sorted, isolated fine deposit comprising the streambed of Boone Creek. Ryan et al. (2006) also found that urbanization often causes increased silt-clay content in streambeds which can lead to a decreased rate of hyporheic exchange and decreased cross sectional area of the hyporheic exchange zone in streams. The presence of plants along the banks of Winkler Creek site adds another dimension of exchange not found along the banks of the more sparsely vegetated Boone Creek. The greater lateral exchange between stream and intact riparian zone induced by preferential flow along plant root zones at Winkler Creek could also explain its long solute residence time by enlarging storage zones.

The overall influence of transient storage on solute transport was assessed via the dimensionless metrics $F_{\text {med }}$. The $F_{\text {med }}$ values are $0.35 \%$ and $1.05 \%$, suggesting that the time spent in transient storage zones accounts for only $0.35 \%$ and $1.05 \%$ of the reach average median travel time under baseflow conditions for Boone Creek and Winkler Creek, respectively. This suggests that HE is generally negligible in these two creeks. The larger $F_{\text {med }}$ value for Winkler Creek indicates that HE is a more important process than for Boone Creek.

The calculations of various nutrient uptake parameters allows for comparison between the two streams in the nutrient uptakes. It is likely that the higher $U$ and $v_{f}$ values and shorter $S_{w}$ seen in Winkler Creek can be explained by the presence of a healthy and fully intact riparian and hyporheic zones. Given the prevalence of plants all along the bank of Winkler Creek, organic carbon from riparian foliage provides labile carbon substrate as an electron donor to microbes. Denitrification and assimilation can happen quickly and efficiently by microbesin a relatively short distance. In Boone Creek however, nutrients must travel a further distance to find areas to be taken up. The sparseness of vegetation along the stream, thus the lack of organic carbon source, is also the likely cause of the slower $U$ and $v_{f}$. In addition, nutrient uptake efficiency is higher in Winkler Creek probably because of high primary productivity in forested streams.

Stream nitrate uptakes can also be controlled by hydrologic process identified from the transient storage analysis. Hydrologic retention is higher in heterogeneous channels than in simple ones. As a result, lower channel complexity in urban streams leads to shorter contact time of water and nutrients within hyporheic zones of assimilation or denitrification and, thus, lower nutrient retention than unaltered streams. Our results thus suggest that urban streams are transport limited relative to forested streams with respect to nutrient removal.

Our predicted transient storage parameters of both Boone Creek and Winkler Creek were compiled in order to 
compare our values to typical values as determined from past studies (Table 3). Our values of $\alpha$ fall within the typical range from $0.04 \times 10^{-3}$ to $0.7 \times 10^{-3} \mathrm{~s}^{-1}$. All cross-sectional area metrics $\left(A, A_{s}\right.$, and $\left.A_{s} / A\right)$ could be reasonably placed within the typical ranges for those values. The typical value for a stream's dispersion coefficient ranges from $0.05 \mathrm{~L}^{2} / \mathrm{s}$ to $1.3 \mathrm{~L}^{2} / \mathrm{s}$. Our predicted average dispersion coefficient values for Boone and Winkler creek, 1.34 $\mathrm{m}^{2} / \mathrm{s}$ and $1.04 \mathrm{~m}^{2} / \mathrm{s}$ respectively, were at the larger end of this range. Our $F_{\text {med }}$ values fell around lower end of literature values, suggesting minimal $\mathrm{HE}$ in these two creeks. With respect to nutrient uptake metrics, all calculated uptake lengths from the Winkler Creek experiments fell within the typical range from $73 \mathrm{~m}$ to $3183 \mathrm{~m}$ while the values from the Boone Creek experiments almost six times greater than the longest typical uptake length. Calculated $\lambda_{m}$ values in Winkler Creek fell within the range of literature data, while $\lambda_{m}$ in Boone Creek were up to two orders of magnitude lower than the typical value. Finally, all calculated uptake velocities $V_{f}$ fell below the typical range of $4.67 \mathrm{~m} / \mathrm{s}$ to $160 \mathrm{~m} / \mathrm{s}$.

Table 3. Typical transient storage nutrient uptake parameters complied from this and other studies (Taken from Lautz \& Siegel, 2007)

\begin{tabular}{|c|c|c|c|c|c|c|c|c|c|}
\hline Reference & $10^{-3} \alpha(/ s)$ & $A\left(m^{2}\right)$ & $A s\left(m^{2}\right)$ & $A s / A$ & $D\left(m^{2} / s\right)$ & $F_{\text {med }}$ & $\mathrm{S}_{w^{-}}-\mathrm{NO}_{3}^{-}(\mathrm{m})$ & $\lambda_{m}^{-1}-\mathrm{NO}_{3}-(\mathrm{min})$ & $10^{-6} V_{f}-\mathrm{NO}_{3}$ \\
\hline \multirow{6}{*}{ Marti et al. (1997) } & 0.4 & 0.2 & 0.4 & 2 & 0.8 & 8.8 & 189 & 21.4 & 56.8 \\
\hline & 0.06 & 0.32 & 0.288 & 0.9 & 0.8 & 1.6 & 88 & 12.2 & 160 \\
\hline & 0.45 & 0.19 & 0.57 & 3 & 0.5 & 43.2 & 122 & 20.3 & 41 \\
\hline & 0.5 & 0.16 & 1.2 & 7.5 & 1 & 76.4 & 75 & 17.6 & 50 \\
\hline & 0.7 & 0.17 & 1.258 & 7.4 & 0.5 & 85.8 & 125 & 47.3 & 18.5 \\
\hline & 0.48 & 0.14 & 2.492 & 17.8 & 0.5 & 92.8 & 150 & 75.8 & 13 \\
\hline \multirow{6}{*}{$\begin{array}{l}\text { Valett et al. (1996, } \\
\text { 1997) }\end{array}$} & 0.061 & 0.05 & 0.23 & 4.6 & 0.05 & 33.3 & 133 & 170.5 & 11.3 \\
\hline & 0.5 & 0.14 & 0.1 & 0.714 & 0.05 & 19.6 & 738 & 115 & 10.2 \\
\hline & 0.2 & 0.36 & 0.004 & 0.011 & 0.4 & 0.9 & 3183 & 255 & 7.83 \\
\hline & 0.12 & 0.08 & 0.13 & 1.625 & 0.08 & 37.7 & 205 & 136.7 & 9.83 \\
\hline & 0.04 & 0.01 & 0.0008 & 0.08 & 0.05 & 0.6 & 1178 & 130.9 & 4.67 \\
\hline & 0.058 & 0.03 & 0.003 & 0.1 & 0.05 & 1.8 & 782 & 194.5 & 8.5 \\
\hline Haggard et al. (2001) & 0.2 & 1.32 & 0.5 & 0.379 & 1.3 & 12.4 & 3120 & 551.1 & 6 \\
\hline \multirow{2}{*}{ Thomas et al. (2003) } & 0.3 & 0.07 & 0.11 & 1.571 & - & 33.0 & 73 & 24.3 & 31.8 \\
\hline & 0.42 & 0.07 & 0.09 & 1.286 & - & 38.0 & 75 & 15.1 & 57 \\
\hline \multirow{3}{*}{$\begin{array}{l}\text { Lautz \& Siegel } \\
\qquad(2007)\end{array}$} & 0.49 & 0.62 & 0.036 & 0.058 & 0.35 & 3.2 & 500 & 32.4 & 105 \\
\hline & 0.163 & 0.672 & 0.00517 & 0.008 & 0.596 & 0.183 & 13500 & 1890 & 1.94 \\
\hline & 0.0614 & 0.518 & 0.0382 & 0.074 & 2.723 & 0.525 & 17700 & 1920 & 1.91 \\
\hline \multirow{2}{*}{ This study } & 0.0325 & 0.36 & 0.157 & 0.436 & 2.067 & 0.702 & 641 & 38.5 & 0.52 \\
\hline & 0.116 & 0.492 & 0.0812 & 0.165 & 0.326 & 1.4 & 1670 & 124 & 0.161 \\
\hline
\end{tabular}

The extremely long uptake length in Boone Creek indicates the status of nutrient saturation and limited nutrient retention relative to nutrient inputs in this urban streams. The average background nitrate concentration in Boone Creek is about $7 \mathrm{mg} \mathrm{L}^{-1}$ were more than an order of magnitude higher than the other studies in Table 3, which might lead to nutrient saturation so that nitrate may not be as readily transformed in the hyporheic zone and nitrate uptake lengths may be extraordinarily long (Haggard et al., 2001). Our study is consistent with the previous research that explored the nature of nitrogen retention and transformation in urban streams found that urbanization could overwhelm a stream's ability to retain nitrogen (Grimm et al., 2005). Urbanization increased loading of inorganic $\mathrm{N}$ (especially $\mathrm{NO}_{3}{ }^{-}$) from runoff from impervious surfaces or through groundwater contamination. This excessive nutrient enrichment leaves the natural annual $\mathrm{N}$ retention of the hyporheic zone unable to compensate for the increased annual $\mathrm{N}$ inputs. A decrease in channel complexity as a result of urban channelization, incision, and straightening of streams is also a source of the diminished denitrification of urban streams (Grimm et al., 2005). As a result, downstream systems will be subject to higher nitrogen loads, which 
could be detrimental to riparian ecosystems as well as threaten urban groundwater quality and supply.

It is noteworthy of the limitation of this study. The data presented in this study is only from one tracer test at a single reach of each stream. Thus any interpretation on the data should be made cautiously. More future tracer injection experiments at different reaches or streams would make it possible to obtain a more reliable statistical comparison between streams.

\section{Implication on Stream Restoration}

The results from this study indicate stream restoration should aim to improve the ecosystem function by enhancing stream HE and nutrient uptakes. While it has become increasingly recognized that urbanization often leads to stream degradation, there is currently a lack of strategies to address damaged hyporheic exchange (Hester \& Gooseff, 2010). Even though there has been considerable research done on erosion mitigation through stream restoration there is no model that could be used to predict impacts of anthropogenic manipulation of the hyporheic zone (Boulton, 2010). Stream restoration tends to focus almost exclusively on surface systems (Boulton, 2010), and primarily involves modifying the form of the stream with efforts such as changing channel width (Hester \& Gooseff, 2010). Hester and Gooseff (2010) outline three techniques that could be used to recover functional hyporheic flow: enhancing surface-groundwater hydraulic gradients, increasing hydraulic conductivity of sediments, and/or providing sources of carbon to hyporheic sediments. One study has found that manmade riffle-step sequences actually induce hyporheic exchange flow (Kasahara \& Hill, 2006) by setting up a hydraulic gradient between surface and groundwater. The installation of these sequences and other morphologic features could have considerable potential to help reinstate the hyporheic exchange in urbanized reaches of streams. Other proposed forms of hyporheic restoration include sediment coarsening to improve thermal buffering between surface and groundwater, as well as floodplain reforestation through riparian planting (Hester \& Gooseff, 2010). However, the benefits from such efforts have not yet been quantified and it has not yet been researched how benefits could vary with different implementation techniques. Given the influential nature of an urban setting on stream hyporheic exchange, stream restoration has to take into account recovering a functional hyporheic flow. Failure to include HE restoration often leads to little water quality improvement in urban streams (Cockerill \& Anderson, 2014). By quantifying hyporheic deficiencies in an urbanized stream, more effective restoration can be achieved.

\section{Conclusion}

This study confirms the hypothesis that urbanization alters HE and nutrient uptakes within streams. The transient storage metrics quantified in this studyshow that the undisturbed forest stream contains a larger storage zone andgreater solute residence time while the urban stream experiences a faster rate of $\mathrm{HE}$ as well as shorter solute residence time within the stream. Analysis of nutrient uptake metrics revealed that nutrients within the urban stream must travel a further distance to be taken up than the forested stream. Overall, our results support that HE and nutrient uptakes are more important processes within a forested stream than an urban stream. HE within the urban streamis both inefficient and limited with regards to nutrient removal as a result of urban impact.

\section{Acknowledgements}

This work was supported partially by ASU Big Idea grant and RIEEE grant. We thank Jeff Colby for his valuable comments that help improve the manuscript.

\section{References}

Anderson Jr., W. P., Anderson, J. L., Thaxton, C. S., \& Babyak, C. M. (2010). Changes in stream temperatures in response to restoration of groundwater discharge and solar heating in a culverted, urban stream. Journal of Hydrology, 393, 309-320. http://dx.doi.org/10.1016/j.jhydrol.2010.08.030

Anderson Jr., W. P., Storniolo, R. E., \& Rice, J. S. (2011). Bank thermal storage as a sink of temperature surges in urbanized streams. Journal of Hydrology, 409, 525-537. http://dx.doi.org/10.1016/j.jhydrol.2011.08.059

Boulton, A. J., Datry, T., Kasahara, T., Mutz, M., \& Stanford, J. A. (2010). Ecology and management of the hyporheic zone: stream-groundwater interactions of running waters and their floodplains. Journal of the North American Benthological Society, 29, 26-40. http://dx.doi.org/10.1899/08-017.1

Cockerill, K., \& Anderson Jr., W. P. (2014). Creating False Images: Stream Restoration in an Urban Setting. Journal of the American Water Resources Association, 50(2), 468-482. http://dx.doi.org/10.1111/jawr.12131

Coffey, C. L. (2011). The Effects of Impervious Surfaces and Forests on Water Quality in a Southern Appalachian Headwater Catchment: A Geospatial Modeling Approach. Master's Thesis, Appalachian State University, Boone, NC, USA. 
Drummond, J. D., Covino, T. P., Aubeneau, A. F., Leong, D., Patil, S., Schumer, R., \& Packman, A. I. (2012). Effects of solute breakthrough curve tail truncation on residence time estimates: A synthesis of solute tracer injection studies. Journal of Geophysical Research, 117. http://dx.doi.org/10.1029/2012JG002019

Ensign, S. H., \& Doyle, M. W. (2006). Nutrient spiraling in streams and river networks. Journal of Geophysical Research, 111. http://dx.doi.org/10.1029/2005JG000114

Findlay, S. (1995). Importance of surface-subsurface exchange in stream ecosystems: The hyporheic zone. Limnology and Oceanography, 40, 159-164. http://dx.doi.org/10.4319/lo.1995.40.1.0159

Grimm, N. B., Sheibley, R. W., Crenshaw, C. L., Dahm, C. N., Roach, W. J., \& Zeglin, L. H. (2005). N retention and transformation in urban streams (Vol. 24, pp. 626-642).

Haggard, B. E., Storm, D. E., Tejral, R. D., Popova, Y. A., Keyworth, V. G., \& Stanley, E. H. (2001). Stream nutrient retention in three northeastern Oklahoma agricultural catchments. Transactions of the ASAE, 44, 597-605. http://dx.doi.org/10.13031/2013.6120

Hancock, P. J. (2002). Human Impacts on the Stream-Groundwater Exchange Zone. Environmental Management, 296, 763-781. http://dx.doi.org/10.1007/s00267-001-0064-5

Harvey, J. W., \& Bencala, K. E. (1993). The effect of streambed topography on surface-subsurface water exchange in mountain catchments. Water Resources Research, 29, 89-98. http://dx.doi.org/10.1029/92WR01960

Hester, E. T., \& Gooseff, M. N. (2010). Moving Beyond the Banks: Hyporheic Restoration is Fundamental to Restoring Ecological Services and Functions of Streams. Environmental Science and Technology, 44, 1521-1525. http://dx.doi.org/10.1021/es902988n

Huaguo, W. (2002). Describing and Predicting Breakthrough Curves for non-Reactive Solute Transport in Statistically Homogeneous Porous Media. Unpublished doctoral dissertation, Virginia Polytechnic Institute and State University, Blacksburg, Virginia.

Kasahara, T., \& Hill, A. R. (2006). Effects of riffle-step restoration on hyporheic zone chemistry in N-rich lowland streams. Canadian Journal of Fisheries and Aquatic Sciences, 63, 120-133. http://dx.doi.org/10.1139/f05-199

Lautz, L. K., \& Siegel, D. I. (2007). The effect of transient storage on nitrate uptake lengths in streams: an inter-site comparison. Hydrological Processes, 21, 3533-3548. http://dx.doi.org/10.1002/hyp.6569

Marti, E., Grimm, N. B., \& Fisher, S. G. (1997). Pre- and post-flood retention efficiency of nitrogen in a Sonoran Desert stream. Journal of the NorthAmerican Benthological Society, 16, 805-819. http://dx.doi.org/10.2307/1468173

Morrice, J. A., Valett, H. M., Dahm, C. D., \& Campana, M. E. (1997). Alluvial characteristics, groundwater-surface water exchange and hydrological retention in headwater streams. Hydrological Processes, 11 , http://dx.doi.org/10.1002/(SICI)1099-1085(19970315)11:3\%3C253::AID-HYP439\%3E3.0.CO;2-J

Paul, M. J., \& Meyer, J. L. (2001). Streams in the Urban Landscape. Annual Review of Ecological Systems, 32, 333-65. http://dx.doi.org/10.1146/annurev.ecolsys.32.081501.114040

Ranalli, A. J., \& Macalady, D. L. (2010). The importance of the riparian zone and in-stream processes in nitrate attenuation in undisturbed and agricultural watersheds - A review of the scientific literature. Journal of Hydrology, 389, 406-415. http://dx.doi.org/10.1016/j.jhydrol.2010.05.045

Reidy, C., \& Clinton, S. (2004). Down Under: Hyporheic zones and their function. Retrieved from http://www.aocweb.org/AOC/LinkClick.aspx?fileticket=0AmYWz7aw9U\%3D\&tabid=148

Rice, J. S., Anderson Jr., W. P., \& Thaxton, C. S. (2011). Urbanization influences on stream temperature behavior within low-discharge headwater streams. Hydrological Research Letters, 5, 27-31. http://dx.doi.org/10.3178/hrl.5.27

Runkel, R. L. (1998). One-Dimension Transport with Inflow and Storage (OTIS): A Solute Transport Model for Streams and Rivers. Water-Resources Investigations Report.

Runkel, R. L. (2002). A new metric for determining the importance of transient storage. Journal of the North American Benthological Society, 21, 529-543. http://dx.doi.org/10.2307/1468428

Ryan, R. J., \& Packman, A. I. (2006). Changes in streambed sediment characteristics and solute transport in the 
headwaters of Valley Creek, an urbanizing watershed. Journal of Hydrology, 323, 74-91. http://dx.doi.org/10.1016/j.jhydrol.2005.06.042

Ryan, R. J., Larson, P. C., \& Welty, C. (2011). The logistics and mechanisms of conducting tracer injection experiments in urban streams. Urban Ecosyst, 14, 87-117. http://dx.doi.org/10.1007/s11252-010-0144-5

Ryan, R. J., Welty, C., \& Larson, P. C. (2010). Variation in surface water-groundwater exchange with land use in an urban stream. Journal of Hydrology, 392, 1-11. http://dx.doi.org/10.1016/j.jhydrol.2010.06.004

Thomas, S. A., Valett, H. M., Webster, J. R., \& Mulholland, P. J. (2003). A regression approach to estimating reactive solute uptake in advective and transient storage zones of stream ecosystems. Advances in Water Resources, 26, 965-976. http://dx.doi.org/10.1016/S0309-1708(03)00083-6

Trimmer, M., Grey, J., Heppell, C. M., Hildrew, A. G., Lansdown, K., Stahl, H., \& Yvon-Durocher, G. (2012). River bed carbon and nitrogen cycling: State of play and some new directions. Science of the Total Environment, 434, 143-158. http://dx.doi.org/10.1016/j.scitotenv.2011.10.074

Turner, A. B., Colby, J. D., Csontos, R. M., \& Batten, M. (2013). Flood Modeling Using a Synthesis of Multi-Platform LiDAR Data. Water, 5, 1533-1560. http://dx.doi.org/10.3390/w5041533

Velísková, Y., Sokáč, M., \& Dulovičová, R. (2009). Determination of Longitudinal Dispersion Coefficient in Sewer Networks. International Symposium on Water Management and Hydraulic Engineering.

Wondzell, S. M. (2005). Effect of morphology and discharge on hyporheic exchange flows in two small streams in the Cascade Mountains of Oregon, USA. Hydrologic Processes, 20, 267-287. http://dx.doi.org/10.1002/hyp.5902

\section{Copyrights}

Copyright for this article is retained by the author(s), with first publication rights granted to the journal.

This is an open-access article distributed under the terms and conditions of the Creative Commons Attribution license (http://creativecommons.org/licenses/by/3.0/). 